\title{
Willingness to Pay More: The Quest for Superstar Museums
}

\author{
Nuria Recuero Virto \\ Universidad Complutense de Madrid, Spain \\ nrecuero@ucm.es \\ María Francisca Blasco López \\ Universidad Complutense de Madrid, Spain \\ fblasco@ucm.es \\ Juan Antonio Mondejar \\ Universidad Castilla-La Mancha, Spain \\ juanantonio.mondejar@uclm.es
}

Museum managers constantly focus their efforts on gaining economic viability. This has become a key challenge as the offer of 'experience economy' attractions is increasingly rising and visitors are searching for experiences that are competitive. Although it has been stated that a picture paints a thousand words, the main objective of this research is determining if the relationship between museum image and visitors' satisfaction significantly and positively influences their willingness to pay more. Partial least analysis was used to conduct the multi-group comparison by including the recently developed measurement invariance of composites (м гсом) and new permutation methods. A total of 529 valid responses of museum visitors were obtained. Interestingly, the findings showed that there were no significant differences between the two museum samples, and that all the relationships analysed were positive and significant. Interestingly, Henseler's MG A identified a slight difference between the two museum visitor samples in the linkage between visitors' satisfaction and visitors' word of mouth. This research proposes a multi-group comparison study examining two different samples of visitors to two superstar Mexican museums so that findings provide useful generalizations that imply academic and managerial contributions for the tourism industry.

Keywords: multi-group, satisfaction, image, willingness to pay more, word of mouth

(cc)BY-SA https://doi.org/10.26493/2335-4194.14.101-114

A museum's function is not only to operate as an economic development engine but also as a destination icon (Carey et al., 2012; Moreno-Gil \& Ritchie, 2009; Sheng \& Lo, 2010; Vu et al., 2018). In this context, museum managers are constantly focusing their efforts on maintaining and raising visitor numbers by fostering their satisfaction in a gradually more saturated 'experience economy' marketplace (Evrard \& Krebs, 2017;
Harrison \& Shaw, 2004; Han \& Hyun, 2017; McLean, 1994; Ober-Heilig et al., 2014). Meanwhile, governments are expecting that certain places increase visitor numbers, so these gain economic viability, and visitors are demanding experiences that are 'value for money' (Ferrari et al., 2018; Gázquez-Abad et al., 2014; Mondéjar-Jimenez et al., 2010; Pop \& Borza, 2016; Recuero et al., 2017). 
The importance of word of mouth (шом) advocacy has been acknowledged, as it is one of the key reasons for museum visiting (Hausmann, 2012). wo M is considered one of the most effective tourism communication channels as those customers that spread the word among their family and friends are far more credible and trustworthy than market-oriented strategies (Confente, 2015; Wang et al., 2017). Likewise, museum pricing has generated substantial attention among many scholars as entry profits have always been considered a fundamental source of income (e.g. Rentschler et al., 2007; Sharifi-Tehrani et al., 2013; Steiner, 1997; Frey \& Steiner, 2012).

Throsby and Withers (1979), in the context of the arts, introduced willingness to pay (W T P) and contingent valuation ( $\mathrm{CVM}$ ) concepts, with some particularities regarding people's willingness to pay (Kim et al., 2010). The intrinsic value of art implies that people may lack the level of information required to make a decision, and have difficulties in measuring it quantitatively (Throsby, 2003). Due to this situation, other scholars have suggested choice modelling to approach museum pricing strategies as this methodology takes into account the attractiveness of the features' characteristics (e.g. Burton et al., 2009; Choi et al., 2010). Although scholars have analysed w TP in museums (e.g. Plaza, 2010; Tohmo, 2004), scant literature has been found that analyses the impact of satisfaction on willingness to pay more (WPM) in the museum context (Bigné et al., 2008).

Tourism scholars have described image as a combination of perceptions, impressions and feelings, which in essence comprises cognitive - pondering beliefs - and affective - feelings - components (Chi \& Qu, 2008; Min et al., 2013; Moreno-Gil \& Ritchie, 2009; Stylos et al., 2016; Whang et al., 2016; Wu, 2015). In this regard, no research has been found that analyses museum image effect on satisfaction.

This study aims to determine the positive and significant relationship between museum satisfaction on WOM and WPM, and between museum image and satisfaction. The research setting has been the Frida Kahlo and Anahuacalli museums. As far as we know, this is the first attempt to employ partial least multigroup analysis to test the aforementioned relation- ships. The objective is important because museumgoers' behavioural outcomes research is scarce and is in need of empirically verified generalizations.

\section{Theoretical Framework}

\section{Museum Satisfaction as a Driver of WOM}

and Willingness to Pay More

Since the beginning of the decade, museums have become market-oriented; focusing ever more on the needs of their visitors as these provide an income source that enhances the social and economic welfare of local communities (Moreno-Gil \& Ritchie, 2009; Stylianou-Lambert, 2011; Yamada \& Fu, 2012). In the tourism paradigm, satisfaction is commonly employed as a critical ratio for the assessment of the cognitive and affective elements of travel experiences (Camarero \& Garrido, 2011; Han \& Hyun, 2017; Mason \& Paggiaro, 2012; Wang \& Wu, 2011) that visitors always associate against their expectations (Agyeiwaah et al., 2016) to generate a subjective reference framework that helps them create comparative judgments (Campón-Cerro et al., 2017).

Museum visitors demand participation, learning options, and enjoyment from the museum experience (Del Chiappa et al., 2013; McIntyre, 2009; Trinh \& Ryan, 2013; Yamada \& Fu, 2012). Museumgoers, to evaluate their perceived overall performance, take into account the functional features the tourist resource offers - staff attention, facilities and convenience - and the affective components - emotional, epistemic and social elements (Bigné et al., 2008; Del Chiappa et al., 2014). Hence, it is reasonable that satisfaction has been considered a key predictor of consumers' behaviour (Kuikka \& Laukkanen, 2012) and, consequently, an imperative requisite for long-term museum success (Brida et al., 2016; Kim et al., 2012).

Scholars have suggested as reasons for the appearance of a positive Wом intention altruistic motives the aspiration to help others, instrumental motivations - the need to show wisdom, and cognitive dissonance reduction purposes - reaffirming themselves and others about the service selection (Simpson \& Siguaw, 2008). In the case of museums, this advocacy has been referred to as a crucial promotional tool that merges as a post-purchase behaviour (Harrison \& Shaw, 2004). 
In this respect, since the early 9os it has been noted that to achieve a positive wом, museum managers must initially ensure visitors' satisfaction (e.g. DiMaggio, 1985; McLean, 1994; Hume et al., 2007; Brida et al., 2016). This type of communication has a significant role in the museum industry as visitors normally share their opinions online and offline (Hausmann, 2012).

Scholars have emphasized that visitors unconsciously generate positive and negative behavioural outcomes after a tourism service experience (Tian-Cole et al., 2002; Tsai \& Wang, 2017), and that those visitors that feel satisfied are normally predisposed to recommend the place and pay more (Cevdet \& Erkut, 2015). As discussed above, it has been suggested that museum satisfaction might be a driver of the museum wо . This linkage has been widely proved to be positive and significant in different services industries (e.g. Babin et al., 2005; Ladhari et al., 2008) and more precisely in tourism (Simpson \& Siguaw, 2008; Kim et al., 2009; Prebensen et al., 2010). In the study context, Harrison and Shaw (2004) found a positive relationship between these two dimensions in a small metropolitan museum in Australia. Also, Camarero and Garrido (2011) proved this relationship to be positive and significant in a research conducted in Patio Herreriano Contemporary Spanish Art Museum with 133 valid answers. However, Trinh and Ryan (2013) could not support that highly satisfied visitors tend to recommend a specific museum to others in a research conducted in the Cham Museum of Vietnam. Despite this controversy, it seems rational to expect that visitors that feel satisfied will have the behavioural outcome of spreading the word among their friends and relatives.

Although W PM has been recognized as a significant matter in museums, and in tourism services in general, limited studies have analysed the drivers of this behavioural attitude (Ladhari et al., 2008). Tourism scholars have concluded that satisfaction has a positive and significant effect on WPM. In this regard, several researchers have proved this linkage to be positive and significant in the hotel industry (Barsky \& Nash, 2002; Lee et al., 2010; Lin, 2016) and in restaurants (Ladhari et al., 2008; Heung \& Gu, 2012). In ad- dition, it has been found that this relationship has only been studied once in the museum industry. Bigné et al. (2005) found this linkage insignificant in a theme park, but Bigné et al. (2008) revealed that satisfaction has a positive and significant effect on W PM in a museum context, while it was again found to be negative in the theme park setting. It seems likely that if museumgoers are satisfied they will likely be predisposed to pay more. Based on the previous discussion, the following hypotheses were developed.

$\mathrm{H} 1$ Museum satisfaction has a positive and significant effect on (a) museum Wом and (b) WPM.

\section{Museum Image Impact on Satisfaction}

Museum image has been considered as a perceptual phenomenon difficult to define as it is determined by subjectivity, and both aspects, cognitive and affective, provide a global image of the tourism service (Beerli \& Martín-Santana, 2004; Martínez \& Pina, 2009; Wu, 2016). However, in tourism literature, there is an absence of a universal definition or an accepted scale to define image, due to lack of homogeneity of the attributes that define this concept (Beerli \& MartínSantana, 2004). Additionally, it has been asserted that image has been affected with the proliferation of online information (Molinillo et al., 2018), which has denoted the relevance of adequate management of this dimension. In addition, it has been stated that heritage has been used in cultural tourism to promote positive images of a place or site (Secondi et al., 2011).

Museum image has also been considered as a component of brand personality (Liu et al., 2013). Scant literature has extensively analysed the dynamics of museum image. In reference to residents' perceptions, several researchers concluded that residents normally generate positive images concerning the local museum (Rosenberg et al., 1960; Vaughan, 2001). Also analysed have been visitors' impressions showing that foreign visitors were influenced by the destination images of Hawaii and expected a learning experience of Native Hawaiian culture from the museum visit (Harrison, 1997). In addition, Moreno-Gil and Ritchie (2009) examined the image formation process from both perspectives. They pointed out that overall image has a positive effect on satisfaction in both cases. 
Incidentally, it has been indicated that a positive preconceived image of a place has a favourable impact on the individual's expectations of the upcoming experience (Chi \& Qu, 2008; del Bosque \& San Martin, 2008). It has been specified that image is a relevant indicator of satisfaction (Leung et al., 2011), which has been supported by numerous tourism studies that have examined this effect (Assaker et al., 2011; Chi \& $\mathrm{Qu}$, 2008; Loi et al., 2017; Prayag, 2009; Wang \& Hsu, 2010). In general, past findings have proved that image is a direct antecedent of satisfaction.

$\mathrm{H} 2$ Museum image has a positive and significant effect on museum satisfaction.

\section{Methodology}

\section{Data Collection Procedure and Sample Profile}

The study was conducted in the Frida Kahlo and Anahuacalli museums. The Frida Kahlo museum can be considered a superstar museum due to the Mexican cultural icon, whereas Anahuacalli is a more modest and traditional museum. The management of both museums is assigned to the same team. Since a high response rate was desired, and the research involved a population that visits the museums, the personal survey method was selected (Lee, 2013; Xu \& Fox, 2014). Trained interviewers gathered data outside the museums from those visitors that had already visited them, either in English or Spanish depending on the origin of participants, from the 18th of March to the 16 th of June 2016. Several precautions were taken to reduce common method variance (смv), following Podsakoff et al.s (2003) recommendations. For instance, to minimize evaluation apprehension, respondents were informed about the purpose of the study and were assured confidentiality and anonymity. In addition, to avoid field researchers' selection bias, the interviewers were instructed to look for a similar portion of male and female participants in various age groups (Kim et al., 2006).

$\mathrm{G}^{\star}$ Power 3 was used to perform power analysis (Faul et al., 2007) and both sample sizes guaranteed power for the $R^{2}$ deviation from zero test as the results in both cases were above 95 per cent for the model proposed in Figure 1 (Cohen, 1988). Therefore, the

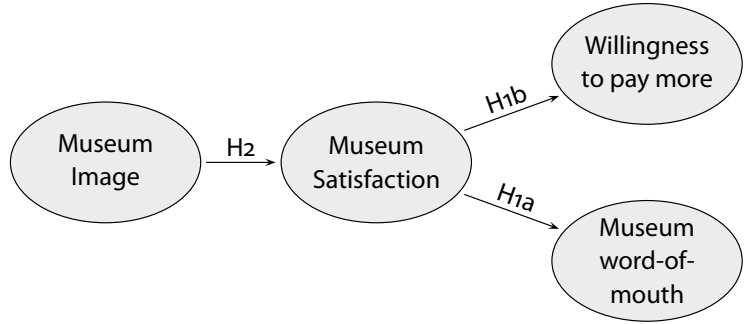

Figure 1 Theoretical Model and Hypotheses

statistical power of 325 and 204 for the two groups examined in this research are acceptable sample sizes. In addition, Harman's single-factor test was conducted to check CMV (Podsakoff et al., 2003) using principal components without rotation in SPPS, and the analysis returned that a single factor explained 36.8 per cent of the variance in the Frida Museum sample case and 48.7 per cent of variance in Anahuacalli Museum sample, which implies a low level of common method bias in the research design.

Convenience sampling was used as it permits reaching a substantial number of respondents that are willing to participate in the study, and saves costs and time in collecting data (Sinclair-Maragh, 2017). Of the 345 Frida Kahlo visitors and 216 Anahuacalli visitors that were invited to participate, 325 and 204, respectively, provided usable questionnaires for the research. The rate of response of 94 per cent in both cases $(325 / 345$ and 204/216) points out that sample bias would not be an issue (Fowler, 1984; Yuksel et al., 2010). Respondents were mainly national, female, aged from 26 to 35 and undergraduates or graduates that have only visited the museums once (Table 1). Table 2 shows the measurement model and the descriptive analysis. In brief, the mean values indicate that Frida Kahlo Museum visitors value slightly better all the dimensions of the proposed model than Anahuacalli Museum visitors. In addition, willingness to pay more seems to be the least valued factors in both samples.

\section{Measurement Model}

A seven-point Likert scale measured all items. $\mathrm{Mu}$ seum image was adapted from $\mathrm{Wu}$ (2015). Four items from the scale developed by Kuikka and Laukkanen (2012) were used to operationalize museum satisfac- 
Table 1 Sample Profile

\begin{tabular}{|c|c|c|c|c|c|}
\hline \multicolumn{2}{|c|}{ Characteristics } & \multicolumn{2}{|c|}{ Frequency } & \multicolumn{2}{|c|}{ Percentage } \\
\hline & & (1) & (2) & (1) & (2) \\
\hline \multirow[t]{2}{*}{ Gender } & Female & 203 & 117 & 62.5 & 57.4 \\
\hline & Male & 122 & 87 & 37.5 & 42.6 \\
\hline \multirow[t]{7}{*}{ Age } & $<17$ & 26 & 24 & 8.0 & $13 \cdot 3$ \\
\hline & $18-25$ & 83 & 63 & 25.5 & 34.8 \\
\hline & $26-35$ & 126 & 77 & 38.8 & 42.5 \\
\hline & $36-45$ & 51 & 22 & 15.7 & 12.2 \\
\hline & $46-55$ & 21 & 10 & 6.5 & 5.5 \\
\hline & $56-65$ & 12 & 6 & $3 \cdot 7$ & $3 \cdot 3$ \\
\hline & $>66$ & 6 & 2 & 1.8 & 1.7 \\
\hline \multirow[t]{4}{*}{ Education } & Postgraduate & 79 & 48 & $24 \cdot 3$ & 23.8 \\
\hline & Undergrad./grad. & 194 & 125 & 59.7 & 61.9 \\
\hline & Secondary & 49 & 29 & 15.1 & 14.4 \\
\hline & Primary & 3 & 2 & 0.9 & \\
\hline \multirow{4}{*}{$\begin{array}{l}\text { No. of } \\
\text { times } \\
\text { visited }\end{array}$} & 1 & 256 & 168 & 78.8 & 82.4 \\
\hline & $2-4$ & 58 & 29 & 17.8 & 14.2 \\
\hline & $5-8$ & 6 & 5 & 1.8 & 2.5 \\
\hline & $>9$ & 5 & 2 & 1.5 & 1.0 \\
\hline \multirow[t]{6}{*}{ Origin } & Asia & 6 & 1 & 1.8 & 0.5 \\
\hline & Europe & 26 & 15 & 8.0 & $7 \cdot 4$ \\
\hline & Latinoamerica & 50 & 40 & 15.4 & 19.6 \\
\hline & National & 161 & 130 & 49.5 & 63.7 \\
\hline & Oceania & 4 & 4 & 1.2 & 2.0 \\
\hline & USA & 78 & 14 & 24.0 & 6.9 \\
\hline
\end{tabular}

Notes Column headings are as follows: (1) Frida Kahlo Museum, (2) Anahuacalli Museum.

tion. Museum wом was captured using SirakayaTurk et al's (2015) scale. Willingness to pay more was measured using Bigné et al.s (2008) scale.

\section{Data Analysis}

Smartpls (version 3.2.7; Ringle et al., 2015) was employed to accomplish the Partial Least Squares Structural Equation Modelling (PLS-SEM) and multi-group (MGA) analyses, as this nonparametric SEM method is very suitable for MGA (Hair et al., 2014; Henseler et al., 2016; Sarstedt et al., 2011). Also, PLS-SEM has a minimum requirement concerning sample size as this tech- nique is based in oLs regressions and it is less severe when it operationalizes with non-normal data (Hair et al., 2014).

\section{Results}

\section{Assessment of the Measurement Model}

and Invariance Measurement Across Groups

Table 3 presents the results of the measurement model reliability and convergent validity test for both samples. All loading factors were above 0.7 , except for three (MI3, MW 2 and MW4). MI3 was dropped and MW 2 and MW 4 were retained as the cronbach alpha and AVE values were not altered, ensuing from Hair et al.s (2014) recommendations. The internal consistency of the study was determined through construct reliability, where the cronbach's alpha coefficients were higher than o.6o. Composite reliability coefficients were higher than the recommended value of 0.60 , specifying the shared variance among a set of observed items measured qpazimeasuring each construct (Fornell \& Larcker, 1981). The examination of convergent validity and discriminant validity confirms the validity of the results (Hair et al., 2011). Consistently, convergent validity was proved, as the average variance extracted (AVE) coefficient for each construct was above 0.50 (Fornell \& Larcker, 1981).

In addition, discriminant validity was confirmed by examining the shared variance between pairs of constructs and verifying it is lower than the corresponding AVE (Fornell \& Larcker, 1981), which determined the extent to which each construct differs from other latent variables in the measurement model (Hair et al., 2016) (Tables 4 and 5). In addition, the heterotrait-monotrait (нтмт) ratio method was implemented (Henseler et al., 2015) and all values were lower than 0.90 (Teo et al., 2008).

The acceptability of measurements models and measurement invariance were verified before examining MGA (Hair et al., 2016; Henseler et al., 2016; Rasoolimanesh et al., 2016; Rasoolimanesh et al., 2017; Sarstedt et al., 2011). The measurement invariance of composites (МІсом) assesses the measurement invariance so as to compare and deduce MGA's groupspecific differences of PLS-SEM results (Henseler et al., 2016). The evaluation of місом entails three steps: 
Table 2 Descriptive Analysis

Construct/Associated Items

$\frac{\text { Frida Kahlo }}{(1) \quad(2)} \frac{\text { Anahuacalli }}{(1) \quad(2)}$

Museum image (MI)

1. The Frida Kahlo Museum/The Anahuacalli Museum has something special

2. The Frida Kahlo Museum/The Anahuacalli Museum has a unique identity

$\begin{array}{llll}6.655 & 0.696 & 6.276 & 1.188\end{array}$

3. The Frida Kahlo Museum/The Anahuacalli Museum is very famous.*

$\begin{array}{llll}6.702 & 0.688 & 6.426 & 1.075\end{array}$

4. The Frida Kahlo Museum/The Anahuacalli Museum is attractive

$\begin{array}{llll}6.098 & 1.335 & 4.397 & 1.747\end{array}$

Museum satisfaction (MS)

1. I am pleased with the service received from the museum's employees

$\begin{array}{llll}6.582 & 0.734 & 6.167 & 1.168\end{array}$

2. I am happy with the panels, installations and the atmosphere created for the museum visit

3. I am content with the educational experience received in the visit to this museum

$\begin{array}{llll}6.305 & 1.188 & 6.152 & 1.257\end{array}$

$\begin{array}{llll}6.440 & 0.970 & 6.212 & 1.153\end{array}$

4. Overall, I am satisfied with this museum

$\begin{array}{llll}6.176 & 1.240 & 5.922 & 1.311\end{array}$

Museum wom (MW)

1. I will mention The Frida Kahlo Museum/The Anahuacalli Museum as a tourist attraction of Mexico City to others quite frequently

2. I will tell more people to visit The Frida Kahlo Museum/The Anahuacalli Museum before other tourist attractions of Mexico City

3. I will seldom miss an opportunity to tell others about The Frida Kahlo Museum/The Anahuacalli Museum

4. When I tell others about The Frida Kahlo Museum/The Anahuacalli Museum, I will also talk about the city in detail

$\begin{array}{llll}6.563 & 0.765 & 6.304 & 1.182\end{array}$

$\begin{array}{llll}6.695 & 0.778 & 6.279 & 1.195\end{array}$

$\begin{array}{llll}5.938 & 1.294 & 5.819 & 1.369\end{array}$

$\begin{array}{llll}6.131 & 1.300 \quad 5.936 & 1.473\end{array}$

$\begin{array}{llll}6.071 & 1.245 & 5.730 & 1.351\end{array}$

. I am proud to tell others that I visited The Frida Kahlo Museum/The Anahuacalli Museum

Willingness to pay more (WPM)

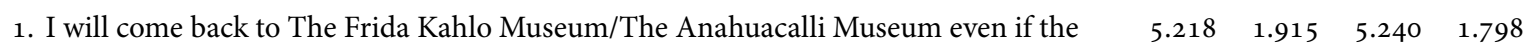
entrance fee increases

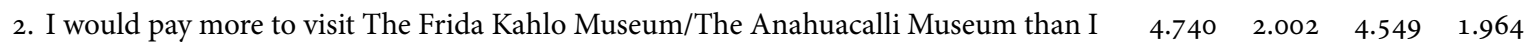
would pay to visit other tourist attractions of Mexico City

Notes Column headings are as follows: (1) mean, (2) standard deviation. ${ }^{\star}$ Dropped during the estimation of the measurement model.

(1) the process of the invariance assessment, (2) the specification of compositional invariance assessment, and (3) the evaluation of equal means and variances (Rasoolimanesh et al., 2017) (Table 6).

\section{Structural Model and Multi-Group Evaluation}

$R^{2}$ was evaluated to measure the model's explanatory power (Hair et al., 2014) and all dependent constructs were higher than o.10 (Falk \& Miller, 1992), reporting substantial and moderate coefficients (Cohen, 1988).
Likewise, positive Stone-Geisser's Q2 were obtained using blindfolding (Henseler et al., 2009), presenting moderate values (Table 7 ).

Table 8 presents the three following different results regarding: (1) the structural model and hypotheses analyses (5,00o bootstrap resamples and 5,00o permutations), (2) Henseler's MGA (Henseler et al., 2009), and (3) the permutation test (Chin \& Dibbern, 2010). Henseler's MGA compares group bootstrap estimates from each bootstrap sample, where the $p$-value that is 
Table 3 Reliability and Convergent Validity of the Final Measurement Model

\begin{tabular}{|c|c|c|c|c|c|c|c|c|c|c|c|c|c|}
\hline \multirow[t]{2}{*}{ Factor } & \multirow[t]{2}{*}{ Indic. } & \multicolumn{6}{|c|}{ Frida Kahlo Museum } & \multicolumn{6}{|c|}{ Anahuacalli Museum } \\
\hline & & (1) & (2) & (3) & (4) & (5) & (6) & (1) & (2) & (3) & (4) & (5) & (6) \\
\hline \multirow[t]{3}{*}{ Museum image } & MI1 & 0.773 & 16,609 & 0.641 & 0.644 & 0.806 & 0.581 & 0.866 & 30,335 & 0.769 & 0.780 & 0.866 & 0.684 \\
\hline & MI2 & 0.724 & 14,106 & & & & & 0.778 & 11,355 & & & & \\
\hline & MI4 & 0.788 & 19,199 & 0.766 & 0.781 & 0.851 & 0.590 & 0.835 & 26,791 & & & & \\
\hline \multirow{4}{*}{$\begin{array}{l}\text { Museum } \\
\text { satisfaction }\end{array}$} & MS 1 & 0.706 & 13,646 & & & & & 0.811 & 18,721 & 0.855 & 0.862 & 0.902 & 0.698 \\
\hline & MS 2 & 0.768 & 18,054 & & & & & 0.806 & 16,663 & & & & \\
\hline & MS 3 & 0.732 & 16,205 & & & & & 0.837 & 24,908 & & & & \\
\hline & MS 4 & 0.858 & 39,435 & & & & & 0.885 & 33,654 & & & & \\
\hline \multirow[t]{5}{*}{ Museum шом } & MW 1 & 0.773 & 15,059 & 0.792 & 0.815 & 0.857 & 0.548 & 0.815 & 21,232 & 0.890 & 0.891 & 0.919 & 0.694 \\
\hline & MW 2 & 0.666 & 10,462 & & & & & 0.802 & 17,170 & & & & \\
\hline & MW 3 & 0.803 & 17,707 & & & & & 0.875 & 31,648 & & & & \\
\hline & MW 4 & 0.620 & 9,453 & & & & & 0.818 & 26,943 & & & & \\
\hline & MW 5 & 0.817 & 23,029 & & & & & 0.855 & 26,431 & & & & \\
\hline \multirow{2}{*}{$\begin{array}{l}\text { Willingness } \\
\text { to pay more }\end{array}$} & WPM 1 & 0.927 & 77,226 & 0.791 & 0.811 & 0.904 & 0.826 & 0.932 & 62,144 & 0.833 & 0.837 & 0.923 & 0.857 \\
\hline & WPM 2 & 0.890 & 44,272 & & & & & 0.920 & 58,080 & & & & \\
\hline
\end{tabular}

Notes Column headings are as follows: (1) standardized loading, (2) $t$-value (bootstrap), (3) CA, (4) rhoA, (5) CR, (6) AVE.

Table 4 Measurement Model Discriminant Validity: Frida Kahlo Museum

\begin{tabular}{lrrrr}
\hline Factor & 1 & 2 & 3 & 4 \\
\hline 1 Museum Image & 0.762 & 0.744 & 0.780 & 0.488 \\
2 Museum Satisfaction & 0.535 & 0.768 & 0.734 & 0.592 \\
3 Museum woM & 0.571 & 0.587 & 0.740 & 0.616 \\
4 Willing. to pay more & 0.359 & 0.465 & 0.496 & 0.909 \\
\hline
\end{tabular}

Notes Diagonal values are AvE square root, values below the diagonal are latent variable correlations, values above the diagonal are нтмт ratios.

less than 0.05 or above 0.95 indicates at the $5 \%$ level significant differences between specific path coefficients across two groups (Henseler et al., 2009; Sarstedt et al., 2011). The permutation test identifies differences at the $5 \%$ level of significance if the $p$-value is less than 0.05 .

The findings show that museum satisfaction has a positive and significant effect on museum wом in both museums (H1a; Frida Kahlo Museum $\beta=0.587$, $p<0.01$; Anahuacalli Museum $\beta=0.739, p<0.01$ ) and on visitors' willingness to pay more (H1b; Frida Kahlo
Table 5 Measurement Model Discriminant Validity: Anahuacalli Museum

\begin{tabular}{lrrrr}
\hline Factor & 1 & 2 & 3 & 4 \\
\hline 1 Museum Image & 0.827 & 0.766 & 0.716 & 0.483 \\
2 Museum Satisfaction & 0.631 & 0.835 & 0.841 & 0.584 \\
3 Museum woM & 0.592 & 0.739 & 0.833 & 0.573 \\
4 Willing. to pay more & 0.387 & 0.495 & 0.494 & 0.926 \\
\hline
\end{tabular}

Notes Diagonal values are AvE square root, values below the diagonal are latent variable correlations, values above the diagonal are нтмт ratios.

Museum $\beta=0.465, p<0.01$; Anahuacalli Museum $\beta=$ $0.495, p<0.01)$. In addition, the results present a positive and significant effect of museum image on museum satisfaction in both samples (H1b; Frida Kahlo Museum $\beta=0.535, p<0.01$; Anahuacalli Museum $\beta=$ $0.631, p<0.01)$.

The permutation method results reveal that there are no significant differences between the Frida Kahlo Museum and Anahuacalli Museum regarding the effects of museum satisfaction on museum wom and willingness to pay more ( $\mathrm{H} 1 \mathrm{a}$ and $\mathrm{H} 1 \mathrm{~b}$ ), and museum 
Table 6 Results of Invariance Measurement Testing Using Permutation

\begin{tabular}{|c|c|c|c|c|c|c|c|c|c|c|c|c|}
\hline \multirow[t]{2}{*}{ Constructs } & \multirow[t]{2}{*}{ (1) } & \multirow[t]{2}{*}{ (2) } & \multirow[t]{2}{*}{ (3) } & \multirow[t]{2}{*}{ (4) } & \multicolumn{4}{|c|}{ Equal mean assessment } & \multicolumn{4}{|c|}{ Equal variance assessment } \\
\hline & & & & & (5) & $(6)$ & (7) & $(8)$ & (5) & (6) & (7) & (8) \\
\hline Museum Image & Yes & 0.998 & 0.992 & Yes & 0.481 & -0.170 & 0.178 & No & $-1,127$ & -0.578 & 0.590 & Yes \\
\hline Museum Satisfaction & Yes & 0.999 & 0.997 & Yes & 0.260 & -0.170 & 0.180 & No & -0.568 & -0.563 & 0.585 & No \\
\hline Museum wом & Yes & 0.997 & 0.997 & Yes & 0.329 & -0.175 & 0.176 & No & -0.713 & -0.496 & 0.525 & No \\
\hline Willing. to pay more & Yes & 1,000 & 0.998 & Yes & 0.043 & -0.175 & 0.173 & Yes & 0.047 & -0.217 & 0.233 & Yes \\
\hline
\end{tabular}

Notes Column headings are as follows: (1) configural invariance (same algorithms for both groups), (2-3) compositional invariance (correlation =1), (2) $\mathrm{C}=1,(3) 5 \%$ quantile, (4) partial measurement invariance established, (5) differences, (6) lower confidence interval, (7) upper confidence interval, (8) equal.

Table 7 Evaluation of the Estimated Models

\begin{tabular}{lcccccc}
\hline Concept & \multicolumn{2}{c}{ Frida Kahlo } & & \multicolumn{2}{c}{ Anahuacalli } \\
\cline { 2 - 3 } & $R^{2}$ & $Q^{2}$ & & $R^{2}$ & $Q^{2}$ \\
\hline Museum Satisfaction & 0.286 & 0.151 & & 0.398 & 0.247 \\
Museum woM & 0.345 & 0.166 & & 0.547 & 0.349 \\
Willigness to pay more & 0.216 & 0.167 & & 0.245 & 0.199 \\
\hline
\end{tabular}

image on museum satisfaction ( $\mathrm{H} 2)$. However, Henseler's MGA spots a slight difference between the two museums in the relationship between museum satisfaction and museum wом (H1a) $(p$-value $=0.958, p$ $<0.05$ ). Henseler's MGA and the permutation method techniques relatedly endorse the significance and nonsignificance of the differences, posing a multi-method confirmation of the findings.

\section{Discussion and Implications}

This research adds value to prior tourism studies by examining the direct impacts of: (1) museum satisfaction on museum WOM and WPM, and (2) museum image on museum satisfaction in two samples, namely Anahuacalli and Frida Kahlo visitors. In this way, this study has examined these different linkages in the two museums in order to pinpoint interesting generalizations in this industry.

The empirical findings show that museum satisfaction has a meaningful and positive effect on museum wом (H1a), as we expected. Although a controversy appeared recently when Trinh and Ryan (2013) concluded that there was an insignificant effect of museum satisfaction on museum wом in the case of a Viet- namese museum, the results of this study corroborate previous findings (Camarero \& Garrido, 2011; Harrison \& Shaw, 2004). In addition, we compared these linkages between the Frida Kahlo and Anahuacalli museums. Interestingly, Henseler's MG A results presented a difference between the two museums in this relationship. Although the effect sizes of both linkages are significant, the Anahuacalli museum case presents a higher influence of museum satisfaction on museum wom. As Table 2 presents, Frida Kahlo respondents valued to a slightly higher extent museum satisfaction and museum wом than Anahuacalli visitors.

The result of this linkage is not due to respondents' evaluation of these dimensions. This difference could be explained by the fact that Anahuacalli respondents might be considering that the museum is not so wellknown and are more willing to spread the word among their relatives and friends than in the other case, as Frida Kahlo has worldwide popularity as a Mexican cultural icon (Aragón, 2014; Dosamantes-Beaudry, 2002; Franco, 1991).

The results confirm the conclusions made by Bigné et al. (2008) that museum satisfaction can positively impact museum WPM ( $\mathrm{H1}$ b), and confirms the results conducted in hospitality studies (Barsky \& Nash, 2002; Ladhari et al., 2008; Lee et al., 2010; Lin, 2016; Heung $\& \mathrm{Gu}, 2012)$. The findings of the MGA confirm there are no significant differences between the two museums, revealing the same size effects in both cases. Besides, as expected, museum image has a positive and significant effect on museum satisfaction ( $\mathrm{H} 2)$, which has been confirmed for the first time in the museum 
Table 8 Hypotheses Testing

\begin{tabular}{|c|c|c|c|c|c|c|c|c|c|c|}
\hline \multirow[t]{3}{*}{ (1) } & \multirow[t]{3}{*}{ Relationship } & \multicolumn{2}{|c|}{ Path coefficients } & \multicolumn{4}{|c|}{ Confidence interval (95\%) } & \multirow[t]{3}{*}{ (2) } & \multicolumn{2}{|c|}{$p$-value difference $\dagger$} \\
\hline & & \multirow[t]{2}{*}{ (3) } & \multirow[t]{2}{*}{ (4) } & \multicolumn{2}{|c|}{ (3) } & \multicolumn{2}{|c|}{ (4) } & & (3) & (4) \\
\hline & & & & Lower & Upper & Lower & Upper & & & \\
\hline H1a & $\begin{array}{l}\text { Museum Satisfaction } \rightarrow \\
\text { Museum wom }\end{array}$ & $0.587^{* * *}$ & $0.739^{\star * *}$ & 0.459 & 0.687 & 0.590 & 0.833 & -0.152 & $0.958^{\star *}$ & 0.111 \\
\hline $\mathrm{H} 1 \mathrm{~b}$ & $\begin{array}{l}\text { Museum Satisfaction } \rightarrow \\
\text { Willingness to pay more }\end{array}$ & $0.465^{* * *}$ & $0.495^{\star * *}$ & 0.369 & 0.550 & 0.368 & 0.599 & -0.030 & 0.662 & 0.687 \\
\hline $\mathrm{H} 2$ & $\begin{array}{l}\text { Museum Image } \rightarrow \\
\text { Museum Satisfaction }\end{array}$ & $0.535^{* * *}$ & $0.631^{* * *}$ & 0.427 & 0.635 & 0.459 & 0.752 & -0.096 & 0.848 & 0.418 \\
\hline
\end{tabular}

Notes Column headings are as follows: (1) hypothesis, (2) path coefficient difference, (3) Frida Kahlo Museum, (4) Anahuacalli Museum, (5) Henseler's MGA, (6) permutation test. ${ }^{\star * *} p<0.01,{ }^{\star *} p<0.05,{ }^{\star} p<0.10 . \dagger$ two-tailed.

industry but was already concluded in tourism studies (Assaker et al., 2011; Chi \& Qu, 2008; Loi et al., 2017; Prayag, 2009; Wang \& Hsu, 2010). The MGA findings also confirm there are no significant differences between the two museums, and the results present the same size effects in both samples.

This study provides several theoretical implications related to museum satisfaction, WOM, WPM and image. First, few museum scholars have examined the impacts of visitors' satisfaction on their behavioural outcomes, wom and wTP (Bigné et al., 2008; Camarero \& Garrido, 2011; Harrison \& Shaw, 2004; Trinh \& Ryan, 2013). Hence, the present research has proposed a model to assess these relationships and the effect of museum image on satisfaction, which has been analysed for the first time in the museum industry. Second, the MGA results have proved that there are no significant differences between museum satisfaction and museum WPM, and between museum image and museum satisfaction, which are interesting findings for the future generalization of the results. In addition, Henseler's MGA results present a difference in the relationship between museum satisfaction and museum WоM, but the PLS-SEM results present both linkages as significant and positive. Hence, these findings extend the generalization of the results. Third, this research contributes not only to museum management literature, but also to tourism research, as it has examined these effects also considering two samples in an MGA approach.

The present study also draws managerial attention to numerous aspects for marketing managers and staff responsible for measuring visitors' satisfaction in museums. First, it has been concluded that visitors' satisfaction positively and significantly influences wом. As шом has been stated as a driver of museum visiting (Hausmann, 2012), it would be interesting to promote communication actions that boost this wom while visitors enjoy the museum experience. Museums could use ambient marketing strategies that are focused on increasing the number of photos shared by visitors in social media, following some of the actions developed by the Museum of Art of Sao Paolo or the Museum of Ice Cream.

Second, it has been proved that satisfaction has a positive and significant effect on W P M. Event though it has been suggested that visitors tend to perceive museums as free of charge or inexpensive entertainment options, especially when these organizations receive public support, it has been concluded that satisfied visitors are predisposed to pay more (Brida et al., 2016; Bigné et al., 2008). Hence, investment in the creation of a hitech edutainment service experience could make museums more competitive in the current Candy Crush and Netflix marketplace. For instance, museums could benefit from the Pokémon Go fever by positioning a market-adjusted image, and increasing their efforts to fulfil the needs of this segment (by placing poskètops, promoting a photocall event, etc.), which would likely improve their W PM.

Third, it has been pinpointed that a well-managed positive image will lead to visitors' satisfaction. In the 
light of the results, it is suggested that managers conduct a specific study for their museums to discover the different components that motivate a positive image for each of their market segments. This will help them improve their promotion strategies by selecting the adequate actions for each segment (Moreno-Gil \& Ritchie, 2009).

\section{Limitations and Future Research Lines}

Scholars are encouraged to encompass the results by bearing in mind the limitations of this research. First, this study has not considered the control variable of first-time or repeated visitors, or other educational or socio-economic factors that would have added interesting insights for the proposed model, as other scholars have previously proposed in related contexts (Beerli-Palacio \& Martín-Santana, 2017; Del Chiappa et al., 2013; Han \& Hyun, 2017). Second, the samples of visitors are of two Mexican museums that have the same management team, which has improved the sample collection but could have led to bias. Although the MGA comparison has presented similar outcomes that allow the generalization of the findings, it would be noteworthy to repeat this study in different museums.

\section{Acknowledgments}

The authors would like to thank the Frida Kahlo and Diego Rivera Anahuacalli museum team for their support, and especially the Directors of both museums, Hilda Trujillo, and Ximena Jordán.

\section{References}

Agyeiwaah, E., Adongo, R., Dimache, A., \& Wondirad, A. (2016). Make a customer, not a sale: Tourist satisfaction in Hong Kong. Tourism Management, 57, 68-79.

Aragón, A. F. (2014). Uninhabited dresses: Frida Kahlo, from icon of Mexico to fashion muse. Fashion Theory, 18(5), 517-549.

Assaker, G., Vinzi, V. E., \& O'Connor, P. (2011). Examining the effect of novelty seeking, satisfaction, and destination image on tourists' return pattern: A two factor, nonlinear latent growth model. Tourism Management, 32(4), 890-901.

Babin, B. J., Lee, Y.-K., Kim, E.-J., \& Griffin, M. (2005). Modeling consumer satisfaction and word-of-mouth: Restau- rant patronage in Korea. Journal of Services Marketing, 19(3), 133-139.

Barsky, J., \& Nash, L. (2002). Evoking emotion: Affective keys to hotel loyalty. Cornell Hotel and Restaurant Administration Quarterly, 43(1), 39-46.

Beerli-Palacio, A., \& Martín-Santana, J. D. (2004). Tourists' characteristics and the perceived image of tourist destinations: A quantitative analysis, a case study of Lanzarote, Spain. Tourism Management, 25(5), 623-636.

Beerli-Palacio, A., \& Martín-Santana, J. D. (2017). How does confirmation of motivations influence on the pre- and post-visit change of image of a destination? European Journal of Management and Business Economics, 26(2), 238-251.

Bigné, J. E., Andreu, L., \& Gnoth, J. (2005). The theme park experience: An analysis of pleasure, arousal and satisfaction. Tourism Management, 26(6), 833-844.

Bigné, E., Mattila, A. S., \& Andreu, L. (2008). The impact of experiential consumption cognitions and emotions on behavioural intentions. Journal of Services Marketing, 22(4), 303-315.

Brida, J. G., Meleddu, M., \& Pulina, M. (2016). Understanding museum visitors' experience: A comparative study. Journal of Cultural Heritage Management and Sustainable Development, 6(1), 47-71.

Burton, C., Louviere, J., \& Young, L. (2009). Retaining the visitor, enhancing the experience: Identifying attributes of choice in repeat museum visitation. International Journal of Nonprofit and Voluntary Sector Marketing, 14(1), 21-34.

Camarero, C., \& Garrido, M. J. (2011). Strengthening members' relationships through cultural activities in museums. Journal of Leisure Research, 43(4), 560-588.

Campón-Cerro, A. M., Hernandez-Mogollón, J. M., \& Alves, H. (2017). Sustainable improvement of competitiveness in rural tourism destinations: The quest for tourist loyalty in Spain. Journal of Destination Marketing and Management, 6(3), 252-266.

Carey, S., Davidson, L., \& Sahli, M. (2012). Capital city museums and tourism flows: An empirical study of the museum of New Zealand Te Papa Tongarewa. International Journal of Tourism Research, 15(6), 554-569.

Cevdet, M., \& Erkut, B. (2015). Cultural tourism in Istanbul: The mediation effect of tourist experience and satisfaction on the relationship between involvement and recommendation intention. Journal of Destination Marketing \& Management, 4(4), 213-222.

Chi, C. G. Q., \& Qu, H. (2008). Examining the structural relationships of destination image, tourist satisfaction and 
destination loyalty: An integrated approach. Tourism Management, 29(4), 624-636.

Chin, W. W., \& Dibbern, J. (2010). A permutation based procedure for multi-group PLS analysis: Results of tests of differences on simulated data and a cross-cultural analysis of the sourcing of information system services between Germany and the Us A. In E. V. Vinzi, W. W. Chin, J. Henseler, \& H. Wang (Eds.), Handbook of partial least Squares: Concepts, methods and applications (pp. 171193). Springer.

Choi, A. S., Ritchie, B. W., Papandrea, F., \& Bennet, J. (2010). Economic valuation of cultural heritage sites: A choice modelling approach. Tourism Management, 31(2), 213220.

Cohen, J. (1988). Statistical power analysis for the behavioural sciences. Lawrence Erlbaum.

Confente, I. (2015). Twenty-five years of word-of-mouth studies: A critical review of tourism research. International Journal of Tourism Research, 17(6), 613-624.

Del Bosque, I. R., \& San Martin, H. (2008). Tourist satisfaction: A cognitive-affective model. Annals of Tourism Research, 35(2), 551-573.

Del Chiappa, G., Andreu, L., \& Gallarza, M. G. (2014). Emotions and visitors' satisfaction at a museum. International Journal of Culture, Tourism and Hospitality Research, 8(4), 420-443.

Del Chiappa, G., Ladu, M. G., Meleddu, M., \& Pulina, M. (2013). Investigating the degree of visitors' satisfaction at a museum. Journal of Tourism and Hospitality Research, 24(1), 52-62.

DiMaggio, P. J. (1985). When the profit is quality: Cultural institutions in the marketplace. Museum News, 63(5), 2835 .

Dosamantes-Beaudry, I. (2002). Frida Kahlo: The creation of a cultural icon. The Arts in Psychotherapy, 29(1), 3-12.

Evrard, Y., \& Krebs, A. (2017). The authenticity of the museum experience in the digital age: The case of the Louvre. Journal of Cultural Economics, 42(2). https://doi.org/ 10.1007/s10824-017-9309-X

Falk, R. F., \& Miller, N. B. (1992). A primer for soft modelling. University of Akron Press.

Faul, F., Erdfelder, E., Lang, A. G., \& Buchner, A. (2007). $\mathrm{G}^{\star}$ Power 3: A flexible statistical power analysis program for the social, behavioural, and biomedical sciences. Behaviour Research Methods, 39(2), 175-191.

Ferrari, G., Mondéjar-Jiménez, J., \& Secondi, L. (2018). Tourists' expenditure in tuscany and its impact on the regional economic system. Journal of Cleaner Production, $171,1437-1446$.
Fornell, C., \& Larcker, D. (1981). Structural equation models with unobservable variables and measurement error. Journal of Marketing Research, 18(1), 39-50.

Fowler, F. J. (1984). Survey research methods. Sage.

Franco, J. (1991). 'Manhattan will be more exotic this fall:' The iconisation of Frida Kahlo. Women: A Cultural Review, 2(3), 220-227.

Frey, B. S., \& Steiner, L. (2012). Pay as you go: A new proposal for museum pricing. Museum Management and Curatorship, 27(3), 223-235.

Gázquez-Abad, J. C., Huertas-Garcia, R., Vazquez-Gomez, M. D., \& Casas Romeo, A. (2014). Drivers of sustainability strategies in Spain's wine tourism industry. Cornell Hospitality Quarterly, 56(1), 106-117.

Hair, J. F., Ringle, C., \& Sarstedt, M. (2011). PL S-SE M: Indeed a silver bullet. Journal of Marketing Theory and Practice, 19(2), 139-152.

Hair, J. F., Hult, G. T. M., Ringle, C., \& Sarstedt, M. (2014). A primer on Partial Least Squares Structural Equation Modelling (PLS-SEM). Sage.

Hair, J. F., Sarstedt, M., Matthews, L., \& Ringle, C. M. (2016). Identifying and treating unobserved heterogeneity with FIMIX-PLS: Part I - method. European Business Review, $28(1), 63-76$.

Han, H., \& Hyun, S. S. (2017). Key factors maximizing art museum visitors' satisfaction, commitment, and postpurchase intentions. Asia Pacific Journal of Tourism Research, 22(8), 834-849.

Harrison, J. (1997). Museums and touristic expectations. Annals of Tourism Research, 24(1), 23-40.

Harrison, P., \& Shaw, R. (2004). Consumer satisfaction and post-purchase intentions: An exploratory study of museum visitors. International Journal of Arts Management, 6(2), 23-32.

Hausmann, A. (2012). The importance of word of mouth for museums: An analytical framework. International Journal of Arts Management, 14(3), 32-43.

Henseler, J., Ringle, C. M., \& Sarstedt, M. (2015). A new criterion for assessing discriminant validity in variancebased structural equation modelling. Journal of the Academy of Marketing Science, 43(1), 115-135.

Henseler, J., Ringle, C. M., \& Sarstedt, M. (2016). Testing measurement invariance of composites using Partial Least Squares. International Marketing Review, 33(3), 405-431.

Henseler, J., Ringle, C. M., \& Sinkovics, R. R. (2009). The use of partial least squares path modelling in international marketing. Advances in International Marketing, 20(1), 277-320. 
Heung, V. C. S., \& Gu, T. (2012). Influence of restaurant atmospherics on patron satisfaction and behavioural intentions. International Journal of Hospitality Management, 31(4), 1167-1177.

Hume, M., Mort, G., \& Winzar, H. (2007). Exploring repurchase intention in a performing arts context: Who comes? And why do they come back? International Journal of Nonprofit and Voluntary Sector Marketing, 12(2), 135-148.

Kim, K., Gursoy, D., \& Lee, S. B. (2006). The impact of the 2002 World Cup on South Korea: Comparisons of preand post-games. Tourism Management, 27(1), 86-96.

Kim, K., Hallab, Z., \& Kim, J. N. (2012). The moderating effect of travel experience in a destination on the relationship between the destination image and the intention to revisit. Journal of Hospitality Marketing Management, 21(5), 486-505.

Kim, S. S., Lee, H., \& Chon, K. S. (2010). Segmentation of different types of hallyut ourists using a multinomial model and its marketing implications. Journal of Hospitality \& Tourism Research, 34(3), 341-363.

Kim, T. T., Kim, W. G., \& Kim, H. B. (2009). The effects of perceived justice on recovery satisfaction, trust, wordof-mouth, and revisit intention in upscale hotels. Tourism Management, 30(1), 51-62.

Kuikka, A., \& Laukkanen, T. (2012). Brand loyalty and the role of hedonic value. Journal of Product \& Brand Management, 21(7), 529-537.

Ladhari, R., Brun, I., \& Morales, M. (2008). Determinants of dining satisfaction and post-dining behavioural intentions. International Journal of Hospitality Management, 27(4), 563-573.

Lee, J. S., Hsu, L. T., Han, H., \& Kim, Y. (2010). Understanding how consumers view Green hotels: How a hotel's green image can influence behavioural intentions. Journal of Sustainable Tourism, 18(7), 901-914.

Lee, T. H. (2013). Influence analysis of community resident support for sustainable tourism development. Tourism Management, 34, 37-46.

Leung, D., Law, R., \& Lee, H. A. (2011). The perceived destination image of Hong Kong on Ctrip.com. International Journal of Tourism Research, 13(2), 124-140.

Lin, I. Y. (2016). Effects of visual servicescape aesthetics comprehension and appreciation on consumer experience. Journal of Services Marketing, 30(7), 692-712.

Liu, C. R., Liu, H. K., \& Lin, W. R. (2013). Constructing customer-based museums brand equity model: The mediating role of brand value. International Journal of Tourism Research, 17(3), 229-238.
Loi, L. T. I., So, A. S. I., Lo, I. S., \& Fong, L. H. N. (2017). Does the quality of tourist shuttles influence revisit intention through destination image and satisfaction? The case of Macao. Journal of Hospitality and Tourism Management, 32, 115-123.

Martínez, E., \& Pina, J. M. (2009). Modelling the brand extensions' influence on brand image. Journal of Business Research, 62(1), 50-60.

Mason, M. C., \& Paggiaro, A. (2012). Investigating the role of festival scape in culinary tourism: The case of food and wine events. Tourism Management, 33(6), 1329-1336.

McIntyre, C. (2009). Museum and art gallery experience space characteristics: An entertaining show or a contemplative bathe? International Journal of Tourism Research, 11(2), 155-170.

McLean, F. (1994). Services marketing: The case of museums. The Service Industries Journal, 14(2), 190-203.

Min, K. S., Martin, D., \& Jung, J. M. (2013). Designing advertising campaigns for destinations with mixed images: Using visitor campaign goal messages to motivate visitors. Journal of Business Research, 66(6), 759-764.

Molinillo, S., Liebana-Cabanillas, F., Anaya-Sanchez, F., \& Buhalis, D. (2018). D MO online platforms: Image and intention to visit. Tourism Management, 65(C), 116-130.

Mondéjar-Jiménez, J. A., García-Centeno, M. C., MínguezSalido, R., Mondéjar-Jiménez, J., \& Cordente-Rodríguez, M. (2010). Cultural tourism, using a multicriteria analysis: Spanish world heritage cities. International Journal of Management \& Information Systems, 14(4), 35-43.

Moreno-Gil, S., \& Ritchie, J. R. B. (2009). Understanding the museum image formation process: A comparison of residents and tourists. Journal of Travel Research, 47(4), 480493.

Ober-Heilig, N., Bekmeier-Feuerhahn, S., \& Sikkenga, J. (2014). Enhancing museum brands with experiential design to attract low-involvement visitors. Arts Marketing: An International Journal, 4(1/2), 67-86.

Plaza, B. (2010) Valuing museums as economic engines: Willingness to pay or discounting of cash-flows? Journal of Cultural Heritage, 11(2), 155-162

Podsakoff, P. M., MacKenzie, S. B., Lee, J. Y., \& Podsakoff, N. P. (2003). Common method biases in behavioural research: A critical review of the literature and recommended remedies. Journal of Applied Psychology, 88(5), 879-903.

Pop, I. L., \& Borza, A. (2016). Factors influencing museum sustainability and indicators for museum sustainability measurement. Sustainability, 8(1), 101-123.

Prayag, G. (2009). Tourists' evaluations of destination im- 
age, satisfaction, and future behavioural intentions: The case of Mauritius. Journal of Travel \& Tourism Marketing, 26(8), 836-853.

Prebensen, N., Skallerud, K., \& Chen, J. S. (2010). Tourist motivation with sun and sand destinations: Satisfaction and the wom-effect. Journal of Travel \& Tourism Marketing, $27(8), 858-873$.

Rasoolimanesh, S. M., Ringle, C., Jaafar, M., \& Ramayah, T. (2017). Urban vs. rural destinations: Residents' perceptions, community participation and support for tourism development. Tourism Management, 6o(4), 147-158.

Rasoolimanesh, S. M., Roldán, J. L., Jaafar, M., \& Ramayah, T. (2016). Factors influencing residents' perceptions toward tourism development: Differences across rural and urban world heritage sites. Journal of Travel Research, 56(6), 760-775.

Recuero, N., Blasco, M. F., \& San-Martin, S. (2017). How can European museums reach sustainability? Tourism Review, 72(3), 303-318.

Rentschler, R., Hede, A.-M., \& White, T. R. (2007). Museum pricing: Challenges to theory development and practice. International Journal of Nonprofit and Voluntary Sector Marketing, 12(2), 163-173.

Ringle, C. M., Wende, S., \& Becker, J.-M. (2015). SmartpLs 3 (Version 3.2.7). SmartPLs. http://www.smartpls.com.

Rosenberg, M. J., Hovland, C. J., McGuire, W., Abelson, R. P., \& Brehm, J. W. (1960). Attitude organization and change: An analysis of consistency among attitude components. Yale University Press.

Sarstedt, M., Henseler, J., \& Ringle, C. (2011). Multigroup analysis in Partial Least Squares (PLS) path modelling: Alternative methods and empirical results. Advances in International Marketing, 22(1), 195-218.

Secondi, L., Meseguer-Santamaría, M. L., Mondéjar-Jiménez, J., \& Vargas-Vargas, M. (2011). Influence of tourist sector structure on motivations of heritage tourists. The Service Industries Journal, 31(10), 1659-1668.

Sharifi-Tehrani, M., Verbic, M., \& Chung, J. Y. (2013). An analysis of adopting dual pricing for museums: The case of the national museum of Iran. Annals of Tourism Research, 43, 58-80.

Sheng, J., \& Lo, A. (2010). Evaluating the tourism potential of public museums in Hangzhou: A supply-side perspective. Journal of Travel \& Tourism Marketing, 27(3), 287305.

Simpson, P. M., \& Siguaw, J. (2008). Destination word of mouth: The role of traveller type, residents, and identity salience. Journal of Travel Research, 47(2), 167-182.

Sinclair-Maragh, G. (2017). Demographic analysis of resi- dents' support for tourism development in Jamaica. Journal of Destination Marketing \& Management, 6(1), 5-12.

Sirakaya-Turk, E., Ekinci, Y., \& Martin, D. (2015). The efficacy of shopping value in predicting destination loyalty. Journal of Business Research, 68(9), 1878-1885.

Steiner, F. (1997). Optimal pricing of museum admission. Journal of Cultural Economics, 21(4), 307-333.

Stylianou-Lambert, T. (2011). Gazing from home: Cultural tourism and art museums. Annals of Tourism Research, 38(2), 403-421.

Stylos, N., Vassiliadis, C. A., Bellou, V., \& Andronikidis, A. (2016). Destination images, holistic images and personal normative beliefs: Predictors of intention to revisit a destination. Tourism Management, 53, 40-6o.

Teo, T. S. H., Srivastava, S. C., \& Jiang, L. (2008). Trust and electronic government success: An empirical study. Journal of Management Information Systems, 25(3), 99-132.

Throsby, D. (2003). Determining the value of cultural goods: How much (or how little) does contingent valuation tell us? Journal of Cultural Economics, 27(3), 275-285.

Tian-Cole, S., Crompton, J. L. \& Willson, V. L. (2002). An empirical investigation of the relationships between service quality, satisfaction and behavioral intentions among visitors to a wildlife refuge. Journal of Leisure Research, 34(1), 1-24.

Throsby, D., \& Withers, G. (1979). The economics of the performing arts. Edward Arnold Publishers.

Tohmo, T. (2004). Economic value of a local museum: Factors of willingness-to-pay. The Journal of Socio-Economics, 33(2), 229-240.

Trinh, T. T., \& Ryan, C. (2013). Museums, exhibits and visitor satisfaction: A study of the Cham Museum, Danang, Vietnam. Journal of Tourism and Cultural Change, 11(4), 239-263.

Tsaia, C.-T., \& Wang, Y.-C. (2017). Experiential value in branding food tourism. Journal of Destination Marketing \& Management 6(1), 56-65.

Vaughan, R. (2001). Images of a museum. Museum Management and Curatorship, 19(3), 253-268.

Vu, H. Q., Luo, J. M., Ye, B. H., Li, G., \& Law, R. (2018). Evaluating museum visitor experiences based on usergenerated travel photos. Journal of Travel \& Tourism Marketing, 35(4), 493-506.

Wang, C. Y., \& Hsu, M. K. (2010). The relationships of destination image, satisfaction, and behavioural intentions. Journal of Travel \& Tourism Marketing, 27(8), 829-843.

Wang, C.-Y., \& Wu, L.-W. (2011). Reference effects on revisit intention: Involvement as a moderator. Journal of Travel \& Tourism Marketing, 28(8), 817-827. 
Wang, T. L., Tran, P. T. K., \& Tran, V. T. (2017). Destination perceived quality, tourist satisfaction and word-ofmouth. Tourism Review, 72(4), 392-410.

Whang, H., Yong, S., \& Ko, E. (2016). Pop culture, destination images, and visit intentions: Theory and research on travel motivations of Chinese and Russian tourists. Journal of Business Research, 69(2), 631-641.

$\mathrm{Wu}, \mathrm{C}$. W. (2015). Foreign tourists' intentions in visiting leisure farms. Journal of Business Research, 68(4), 757762.

Wu, C. W. (2016) Destination loyalty modelling of the global tourism. Journal of Business Research, 69(6), 2213-2219.
Xu, F., \& Fox, D. (2014). Modelling attitudes to nature, tourism and sustainable development in national parks: A survey of visitors in China and the U K. Tourism Management, 45, 142-158.

Yamada, N., \& Fu, Y.-Y. (2012). Using the theory of planned behaviour to identify beliefs underlying visiting the Indiana State Museum. Journal of Travel \& Tourism Marketing, 29(2), 119-132.

Yuksel, A., Yuksel, F., \& Bilim, Y. (2010). Destination attachment: Effects on customer satisfaction and cognitive, affective and conative loyalty. Tourism Management, 31(2), 274-284. 